\title{
Interweaving of the Sources and Forms of a Firm's Competitive Advantage: A Critical Review of the Adequacy of Existing Schools of Thought*
}

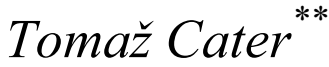

The paper examines how the sources and forms of competitive advantage interweave and what does this mean for the existing theory on competitive advantage. We found out that all sources of competitive advantage should be classified into external and internal category. Consequently, we believe it is reasonable to discuss only two schools, i.e. the 'internal' school based on resources, capabilities and knowledge and the 'external' school based on the industrial organisation. The relation between them should not be understood as being solely competitive but also complementary, which means that the mystery of creating a competitive advantage cannot be explained by any school alone.

Der Aufsatz untersucht, inwiefern die Ursprünge und Formen von Wettbewerbsvorteilen miteinander verflochten sind und wie sich dies auf die Theorie des Wettbewerbsvorteiles auswirkt. Die Ursprünge des Wettbewerbsvorteiles lassen sich in externe und interne Gruppen einteilen. Als Konsequenz daraus ist es sinnvoll, lediglich zwei Ansichten zu diskutieren, die , interne' Lehre, die auf Ressourcen, Fähigkeiten und Wissen zurückgreift und die ,externe', die auf der industriellen Organisation basiert. Die Beziehung der zwei Lehren sollte nicht als konkurriend sondern als ergänzend aufgefasst werden, was bedeutet, dass das Rätsel der Schaffung eines Wettbewerbsvorteiles nicht alleine von einer Lehre erklärt werden kann.

Key words: Firm / competitive advantage / industrial organisation / resources / capabilities / knowledge

\footnotetext{
Manuscript received: 12.02.04, accepted: 25.10 .04 (1 revision)

** Tomaž Cater, Ph.D., Assistant Professor, Faculty of Economics, University of Ljubljana. Main research interests: Sources and forms of competitive advantage of a firm, corporate and business level strategies, planning and controlling. Corresponding address: Tomaz.cater@ef.uni-lj.si
} 


\section{Introduction}

Nowadays, in the era of intense global competition, a discussion on how to enhance a firm's competitiveness in the local and/or global market is probably more relevant than it has ever been. The discussion of the topic takes place literally every day, not only among managers but also among academics, politicians and others. In spite of its relevance, however, the discussion is usually too simplified. It seems that many people do not properly understand how complex the process of competition among firms really is.

In the paper we try to bring the above-mentioned discussion on a higher level, building on a presumption that the process of competition among firms can be described as a causal-consecutive sequence 'sources of competitive advantage, forms of competitive advantage, performance'. In other words, if a firm's primary strategic goal is long-term progress, development and success such firm must first develop certain sources of competitive advantage. Once a firm possesses such sources and knows how to transfer them into at least one form of competitive advantage it can reasonably expect to be successful.

The scientific literature usually discusses four basic schools concerning the sources of competitive advantage, i.e. the industrial organisation school, the resource-based school, the capability-based school and the knowledge-based school, and two fundamental forms of competitive advantage, i.e. lower price (costs) and differentiation. The purpose of this paper is to analyse the interweaving of the sources and forms of a firm's competitive advantage and, based thereon, offer a critical review of the adequacy of existing schools of thought. More specifically, we try to classify all potential sources ${ }^{1}$ of competitive advantage into certain groups, where each group consists of the sources that have mutually high correlation coefficients and at the same time low correlation coefficients with the sources from other groups.

If we were to find that a certain group consists of sources that are discussed by different schools, we could then, at least from one aspect (i.e. by disregarding the environmental context and methodological background based on which each school was developed) conclude that these schools mutually interweave. After briefly reviewing the relevant theory, the paper mainly involves a presentation of the empirical findings of a study of 225 Slovenian $^{2}$ firms $^{3}$. By comparing the

A separate analysis (using the same methodology) is also made for the forms of competitive advantage.

2 Slovenia is a small country with $20.256 \mathrm{~km}^{2}$ of land area and slightly less than 2 million inhabitants. It has a unique strategic position in the heart of Europe, bordering with Italy on west, Austria on north, Hungary on north-east, Croatia on east and south and the Adriatic Sea on south-west. Slovenia declared its independence from Yugoslavia in 1990. Its transition was relatively successful with relatively stable and fast GDP growth. Since May 1st 2004 Slovenia is a full member of the European Union. 
empirical evidence with the theoretical findings drawn from the literature, we believe some new insights can be offered to scholars and researchers in the area of competitiveness.

\section{Sources and forms of competitive advantage of a firm}

\subsection{Four schools of thought on the sources of competitive advantage of a firm}

Within the industrial organisation school there are at least two different views of the origin of a firm's competitive advantage. On one side, there are advocates (for example Mason 1939; Bain 1956) of the so-called classical industrial organisation school who claim that a firm can neither influence industry conditions nor its own performance (Lado et al. 1992; Gadhoum 1998). In this context, the competitive advantage is sourced in external sources (i.e. it is determined by the characteristics of the environment) rather than in internal sources. External sources are especially the structural parameters of the industry such as the bargaining power of suppliers, the bargaining power of buyers, the threat of new entrants, the threat of substitute products or services, and current competition within the industry (Porter 1979) and, at least for those firms that mostly compete against foreign competitors, the basic characteristics of the nation (i.e. national economy) like domestic demand conditions, domestic factor conditions, related and supporting industries within the economy, and domestic rivalry (Porter 1990).

On the other side, there is a modified framework advanced by a new group of industrial organisation scholars which recognises that firms have a certain influence on the relationship between industry structure and a firm's performance (Hansen/Wernerfelt 1989). According to Porter (1981), there are some fundamental parameters of industry but, within those parameters, industrial evolution can take many paths depending (among other things) on the strategic choices firms actually make. Porter (1979) believes a firm's strategic choice regarding the competitive forces in the industry includes positioning a firm so that its capabilities provide the best defence against the competitive forces, influencing the balance of the competitive forces, and/or anticipating and exploiting shifts in the factors underlying the competitive forces.

3 Since the discussion about the sources (particularly within the industrial organisation and resource-based schools) and forms of competitive advantage is usually more reasonable at the strategic business unit (SBU) level than the corporate level (Cater 2003), respondents were asked to take this fact into account. Where a firm was diversified enough to say it has at least two SBUs, respondents were asked to provide answers for the most important SBU. On the other hand, if a firm as a whole was a single SBU respondents were asked to provide answers for the firm as a whole. 
In complete contrast to the industrial organisation school are the resource-based, the capability-based and the knowledge-based schools which all emphasise the internal sources of competitive advantage. This means a competitive advantage is proactively created by firms through the accumulation of unique resources, capabilities and knowledge. The resource-based school rests heavily on the socalled 'resource-based view of the firm' (Penrose 1959; Wernerfelt 1984). This view focuses mostly on an understanding of a firm's resources, their implications for the firm's performance and lately also on the relationship with environmental threats and opportunities (Barney 1986; Mahoney/Pandian 1992; Barney 1996). According to the resource-based school, the competitive advantage of a firm can be built on a firm's resources (Bharadwaj et al. 1993; Hunt 1999) that meet some important conditions such as value, heterogeneity, rareness, durability, imperfect mobility, unsubstitutability, imperfect imitability, and 'ex ante' limits to competition (Cater 2001a).

The literature that deals with the sources of competitive advantage usually classifies a firm's resources into physical, financial, human and organisational resources (Barney 1997). Other authors who prefer to use a different classification also classify a firm's resources as either tangible or intangible resources (Michalisin et al. 1997). Although all resources are important, the literature treats the human and organisational (i.e. the intangible) resources as slightly more relevant for creating a firm's competitive advantage (Zupan 1996; Whitehill 1997).

As its name reveals, advocates of the capability-based school claim that a firm's competitive advantage derives from its capabilities/competencies (Collis 1991; Day 1994). Different authors use different expressions to describe the sources of capability-based competitive advantage. The most common expressions found in the related scientific literature are core skills (Tampoe 1994), distinctive capabilities (Snow/Hrebiniak 1980; Hitt/Ireland 1985), organisational capabilities (Collis 1994), organisational capital (Prescott/Visscher 1980), dynamic capabilities (Eis enhardt/Martin 2000; Luo 2000) and core competencies ${ }^{4}$ (Leonard-Barton 1992; Post 1997). Firms seeking to build their competitive advantage on capabilities should focus on their business processes, transform their key processes into strategic capabilities and make strategic investments to support these capabilities. Since the capabilities on which competitive advantages can be built necessarily extend across the whole firm the champion of any capability-based strategy must be the chief executive officer (Stalk et al. 1992). In the literature capabilities are most frequently classified into managerial, inputbased, transformational, and output-based capabilities (Lado et al. 1992). Clearly, capabilities create no competitive advantage if they are easily achieved (imitated)

4 According to Prahalad and Hamel (1990) core competencies play an especially important role in building a firm's competitive advantage. Based on their thoughts, a new 'sub-school' (based on core competencies) within the capability-based school has emerged in the scientific literature. 
by one's competitors. Thus, the potential sources of competitive advantage are those capabilities that are difficult to develop, meaning they have to be complex (Bartmess/Cerny 1993), diffused throughout the firm (Ulrich 1987), and based upon the cooperation of many individuals/teams within the firm (King et al. 2001).

Advocates of the knowledge-based school concerning the competitive advantage of a firm argue that a firm can win a competitive battle only if it possesses more relevant knowledge than its competitors (Inkpen 1998; Zack 1999). Naturally, from the firm's point of view not all kinds of knowledge are equally useful. Especially important is that part of knowledge that can be labelled commercial knowledge. Its goal is not to find the truth, but to ensure effective performance (Demarest 1997). Knowledge can be classified according to several criteria, two of which are especially important.

The first classification divides the intellectual capital of a firm into human and structural capital (Edvinsson 1997; Edvinsson/Malone 1997). Human capital is based on the employees' knowledge and skills and cannot be the property of a firm. It can only be rented, which means that it is highly risky. On the other hand, structural capital is the property of a firm and can be traded (Edvinsson/Sullivan 1996). For this reason, one of the most important challenges of management is to transform the firm's human capital into its structural capital (Lank 1997).

The second important classification distinguishes between explicit and tacit knowledge (Nonaka/Takeuchi 1995; Teece 1998). Since the former can more easily be copied by competitors, the latter is said to be a more relevant source of competitive advantage (McAulay et al. 1997; Leonard/Sensiper 1998). The growing importance of intellectual capital naturally calls for its systematic management. Knowledge management can be defined as that part of the total management process which focuses on the systematic analysis, planning, accumulation, creation, developing, archiving and exploitation of a firm's knowledge and tries to transform as much of a firm's human capital as possible into its structural capital in order to develop the competitive advantage of a firm and help fulfil its other main objective(s) in an expedient way (Cater 2001c). As such, knowledge management is and must be a cross-functional activity that remains within the competence of a firm's top (strategic) management (Pucko 1998; Cater 2001b).

\subsection{Two basic forms of competitive advantage of a firm}

A competitive advantage can be defined as a unique position (a more detailed discussion on a 'positional' competitive advantage is given by Ma (2000)) that a firm develops in comparison with its competitors. Outward evidence of a competitive advantage is a position of superiority in an industry or market (Bamberger 1989), where the superiority depends on how customers perceive it. Since customers are the ones that make a firm's operations and progress 
possible, the whole idea of competitive advantage should actually be analysed from their perspective. For example, a firm can produce superior products but, so long as the customers do not perceive them as superior, the firm is unlikely to gain a competitive advantage and outperform its competitors. The above understanding of competitive advantage brings us to the conclusion that firms have to compete on superior customer value delivery. They can offer superior value to customers by offering similar products and services as the competitors at a reduced price or by differentiating themselves from the competitors (i.e. offering something the competitors cannot). Two main forms of competitive advantage are therefore lower price and differentiation. The latter can take many different forms, among which the literature usually places the greatest stress on superior product/service, the totality of supply (when a firm has a broad product line and offers support and complementary products/services), speed (fast delivery), flexibility, and the positive image of a firm (Kotha/Vadlamani 1995; Sashi/Stern 1995; Helms/Ettkin 2000).

Another interesting question we need to deal with is the dilemma of simultaneous cost and differentiation advantage. As proposed by Porter (1980), firms mostly cannot choose more than one (cost leadership or differentiation) generic business strategy because implementing either of them requires total commitment and supporting organisational arrangements that are diluted if there is more than one primary target. Although we agree with Porter's idea of 'pure' generic strategies, we believe these strategies should not be seen as synonyms for forms of competitive advantage. In other words, the idea of pure generic business strategies does not directly interfere with the idea of simultaneous cost and differentiation advantage. A firm should indeed concentrate on only one of the generic business strategies, but it can still find itself in a position (for example, due to rare and valuable resources) of having a simultaneous cost and differentiation advantage.

We can therefore agree with many other authors (see, for instance, Flynn et al. 1995; Flynn/Flynn 1996) that a firm can offer a superior (differentiated) product at a lower price. In addition, Karnani (1984) believes both forms of competitive advantage are continuums, where more of one can be a substitute for less of another (trade-off). This means a firm's competitive advantage results from an appropriate combination of a firm's price (cost) and differentiation position.

\section{Methodological background}

\subsection{Research hypotheses}

Reflecting the paper's aim three research hypotheses dealing with the interweaving of the sources and forms of a firm's competitive advantage were developed as follows: 
- H1: The sources of competitive advantage discussed within different schools are interwoven. Hypothesis 1 was developed following the depiction of the relevant theory in section 2.1. Based on the description of the four schools one cannot overlook that the line between different schools is sometimes very thin. This is especially true for the resource-based, capability-based and knowledge-based schools. These schools not only follow the same 'inside-out' logic and discuss similar sources of competitive advantage but also provide similar answers to some other questions. For all these reasons there is a possibility that these schools are at least partly substitutional to each other (Makadok 2001).

- H2: The forms of competitive advantage are interwoven. Hypothesis 2 was developed based on the discussion on the dilemma of simultaneous cost and differentiation advantage in section 2.2. Although the dilemma has been 'resolved' by several authors (see, for example, Flynn/Schroeder/Sakakibara 1995; Flynn/Flynn 1996) we believe it needs further verification, especially in the post-transitional business environment.

- H3: Based on the interweaving of the sources and forms of competitive advantage a redefinition of the existing concepts is required. Hypothesis 3 is a logical consequence of hypotheses 1 and 2 . If we were to find that the sources and forms of competitive advantage interweave in a considerably different manner than proposed by the existing literature, perhaps this could mean that a step-by-step redefinition of the existing concepts is required.

\subsection{The sample of firms, collection of data and description of variables}

Empirical research in this paper forms part of a broader study on the strategic behaviour and competitive advantages of Slovenian firms. Data was collected by sending questionnaires ${ }^{5}$ to the Chief Executive Officers or members of the top management of randomly selected firms by post. In selecting the firms the Gospodarski vestnik ${ }^{6}$ (2002) database was used. As this database includes firms, i.e. economy subjects that are legal persons (not natural persons), from all sectors (industries), size groups, age groups etc., we can say that the target population are all Slovenian firms (i.e. all legal persons within the group of economy subjects). By the end 2002, questionnaires from 225 (out of 508 initially distributed) Slovenian firms had been satisfactorily completed and returned to the author, meaning the response rate was $44.3 \%$. The respondents were mostly Chief Executive Officers (36.4\%), assistant managers (27.6\%) or members of the top management $(25.3 \%)$. In the remaining $10.7 \%$, the respondents were the heads of different (mostly advisory) departments such as controlling, accounting

5 On consultation with leading Slovenian professors of management (in order to assure maximal reasonableness and validity) the questionnaire was designed by the author.

6 Gospodarski vestnik is a leading Slovenian business newspaper publisher. 
etc. If the above structure of respondents holds true, this can be regarded as very satisfactory as in most cases the respondents were individuals who should have fluently mastered the discussed topics.

Because of the broader goals ${ }^{7}$ of the research we used stratified sampling in selecting firms in the sample. The structure of firms in the sample can be shown according to several criteria:

- Legal form: public limited companies (45.3\%), private limited companies (54.7\%);

- Sector: manufacturing (33.3\%), service (34.2\%), trading (32.4\%);

- Size $^{8}$ : large (33.3\%), medium-sized (33.3\%), small (33.3\%);

- Year of foundation: founded in 1989 or earlier (50.7\%), founded in 1990 or later $(49.3 \%)$.

Since the structure of firms in the sample, especially according to the criterion of size distribution, was quite different from the actual structure ${ }^{9}$ of Slovenian firms, it cannot be said that the sample is completely representative. The reason for this primarily lies in the use of stratified sampling which, as already explained, was influenced by the project's broader goals.

In order to test the research hypotheses we had to create two sets of variables, one representing the most relevant sources of competitive advantage and the other representing the most relevant forms of competitive advantage. In other

7 The goals of the research were much wider than the goals presented in this paper. Among other things, we also wanted to examine the differences in the sources and forms of competitive advantage between different groups of firms such as manufacturing, service and trading firms, large, medium-sized and small firms, and so on. In order to have a sufficient number of large firms in the sample, as required to carry out these analyses, stratified sampling was used.

8 The size of the firms in Slovenia (as well as in this research) is statutorily defined. Small firms are those that meet at least two of the following three conditions: (1) average number of employees in the last year does not exceed 50, (2) sales in the last year do not exceed 1 billion SIT, and (3) average assets in the last year do not exceed 0.5 billion SIT. Medium-sized firms are those that are not small and meet at least two of the following three conditions: (1) average number of employees in the last year does not exceed 250, (2) sales in the last year do not exceed 4 billion SIT, and (3) average assets in the last year do not exceed 2 billion SIT. Firms that cannot be defined as small or medium-sized are large firms (Zakon o gospodarskih družbah (ZDG-F) 2001).

9 The actual structure of Slovenian firms shows that at the end of 2001 there were $83.2 \%$ of private limited companies, $8.2 \%$ were general partnerships, $2.6 \%$ were public limited companies, while the remaining firms (6.0\%) involved other legal forms. With regard to the sectors involved, $17.4 \%$ of firms were in the manufacturing sector, $45.4 \%$ were in the service sector, while $37.2 \%$ were in the trading sector. From the aspect of size, there were $95.0 \%$ of small firms, $4.1 \%$ of mediumsized firms, and only $0.9 \%$ of large firms (Statistical Yearbook of the Republic of Slovenia 2002). 
words, based on a study of the relevant scientific literature we designed a list of the most frequently discussed sources of competitive advantage and a list of the most frequently discussed forms of competitive advantage. We defined 116 variables representing the sources (see Figure A1 and Table A1 in the Appendix) and 15 variables representing the forms (see Figure A2 and Table A2 in the Appendix) of competitive advantage. The values of these variables were, as already explained, obtained by sending questionnaires to the managers of selected firms by post. Most questions in the questionnaire required an answer in the form of (dis)agreement with the offered statements. Respondents were asked to choose between five answers (a five-point Likert scale was used), where 1 means they completely disagreed with the statement, whereas 5 means they completely agreed with it. In this way we collected data for both groups of variables, i.e. data for the relevance ( 1 to 5) of each potential source and form of competitive advantage. These data were then used in the statistical analyses (using SPSS for Windows) as discussed in the following sections.

\section{Empirical findings}

\subsection{Interweaving of a firm's sources of competitive advantage}

In hypothesis 1 we examine whether or not the sources of competitive advantage discussed within the different schools are interwoven. Our goal is to classify all potential sources of competitive advantage into certain groups, where each group consists of the sources that have mutually high correlation coefficients and at the same time low correlation coefficients with the sources from other groups. If we were to find that a certain group consists of sources that are discussed by different schools, we could then conclude that these schools mutually interweave, at least in view of the sources of competitive advantage they discuss. Based on our goal we use the clustering method to test hypothesis 1 . Among the several varieties of clustering method we use the 'Within-Groups Linkage' hierarchical method $^{10}$ and Pearson correlation coefficient as the similarity measure.

The results of the clustering method can be very clearly explained by using a dendrogram. As shown in Figure A1 and Table A1 (Table A1 is used to explain the variables' codes in Figure A1) in the Appendix, it is reasonable to discuss six clusters of sources of competitive advantage.

10 The 'Within-Groups Linkage' method proved one of the best in solving similar problems. It groups the objects (sources of competitive advantage) so that the distance between objects within a cluster is minimal, which means that each cluster is as compact as possible. In comparison with Ward's method the 'Within-Groups Linkage' method is especially useful if Pearson's correlation coefficient is used as the similarity measure. The method also has important advantages over some other frequently used methods (Sharma 1996). 
Table 1. The shares of the explained variance of the sources of competitive advantage and the choice of the adequate number of factors

\begin{tabular}{|c|c|c|c|c|c|c|c|c|c|}
\hline \multirow[t]{2}{*}{ Factor } & \multicolumn{3}{|c|}{ Initial values } & \multicolumn{3}{|c|}{$\begin{array}{l}\text { Extraction sums of sq. } \\
\text { loadings }\end{array}$} & \multicolumn{3}{|c|}{ Rotation sums of sq. loadings } \\
\hline & Total & $\%$ of var. & Cumul. \% & Total & $\%$ of var & Cumul. \% & Total & $\%$ of var & Cumul. \% \\
\hline 1 & 40.257 & 34.704 & 34.704 & 40.050 & 34.526 & 34.526 & 23.246 & 20.040 & 20.040 \\
\hline 2 & 16.786 & 14.471 & 49.175 & 16.565 & 14.280 & 48.806 & 19.807 & 17.075 & 37.115 \\
\hline 3 & 12.255 & 10.565 & 59.740 & 12.037 & 10.377 & 59.183 & 14.859 & 12.810 & 49.925 \\
\hline 4 & 10.131 & 8.734 & 68.473 & 9.914 & 8.546 & 67.729 & 12.634 & 10.892 & 60.816 \\
\hline 5 & 4.532 & 3.907 & 72.380 & 4.303 & 3.710 & 71.439 & 9.582 & 8.261 & 69.077 \\
\hline 6 & 2.360 & 2.035 & 74.415 & 2.140 & 1.845 & 73.284 & 4.560 & 3.931 & 73.008 \\
\hline 7 & 1.559 & 1.344 & 75.759 & 1.313 & 1.132 & 74.416 & 1.218 & 1.050 & 74.058 \\
\hline 8 & 1.489 & 1.284 & 77.042 & 1.229 & 1.060 & 75.475 & 1.186 & 1.022 & 75.081 \\
\hline 9 & 1.247 & 1.075 & 78.117 & 1.057 & 0.911 & 76.387 & 1.140 & 0.983 & 76.064 \\
\hline 10 & 1.130 & 0.974 & 79.092 & 0.944 & 0.814 & 77.201 & 1.125 & 0.970 & 77.034 \\
\hline 11 & 1.026 & 0.885 & 79.976 & 0.773 & 0.666 & 77.867 & 0.966 & 0.833 & 77.867 \\
\hline 12 & 0.948 & 0.818 & 80.794 & - & . & - & & & - \\
\hline
\end{tabular}

The first cluster consists of organisational resources, transformational and output-based capabilities, and the knowledge of the firm as a whole, the second cluster is composed of a firm's strategies, human resources, managerial capabilities, and the knowledge of individuals, while the third cluster is made up of physical and financial resources and input-based and some functional capabilities. Clusters four to six represent much more 'external' sources of competitive advantage. The fourth cluster consists of the variables related to the weak bargaining power of suppliers and buyers, the fifth is made up of variables representing mild rivalry among existing firms in the industry and low threats of substitution and new entrants, whereas the sixth cluster includes sources related to the characteristics of the national economy.

Based on the clustering method we can already see some indications of the nature of the interweaving of sources of competitive advantage in Slovenian firms. In spite of this, we additionally test hypothesis 1 by using the factor analysis. Our goal is to detect a small number of latent variables (factors), which throw light on the linkages within a great number of the studied variables and discover their common extensions. Among several possible methods of factor extraction we use one of the most prevalent methods, i.e. the 'Principal Axis 
Factoring' method ${ }^{11}$. To be able to interpret the factors more easily we use the 'Varimax' rotation method. As for the choice of an adequate number of factors several empirical rules can be found in the literature. One of the most prevalent is Kaiser's rule, which suggests that all factors with an initial eigenvalue (second column in Table 1) greater than one should be extracted. Based on this eigenvalue-greater-than-one rule we should discuss the 11 factors in our analysis.

Ultimately, since Kaiser's rule is an empirical rule and only one of many rules used in choosing the number of factors we made an exception and decided to discuss just six factors. The reason for this is not only that six is also the number of clusters resulting from the clustering method but that six factors seems a logical choice based on the percentage of explained variance of the studied variables. As shown in Table 1 (column 9), after rotation the sixth factor still represents about $4 \%$ of the variance of the studied variables, whereas factors seven to eleven only represent about $1 \%$ of the variance.

Once the decision on the number of factors is made, an understandable interpretation of these factors is the next challenge. As already explained, we use the 'Varimax' rotation method to interpret the factors more easily. This rotation method is used to find out which sources of competitive advantage have the highest loadings on a given factor. The results (i.e. the rotated factor matrix) for the most important groups of sources of competitive advantage are shown in Table 2, where the sources are classified according to the factor on which certain sources have the highest loadings. By comparing the variables with the highest loadings on each factor (Table 2) and the variables in each cluster (Table A1) we see that the 'content' of the factors is almost completely identical to the 'content' of the clusters. The only difference is that the variables with the highest loadings on factor 4 mostly coincide with the variables from cluster 5 , whereas the variables with the highest loadings on factor 5 mostly coincide with the variables from cluster 4.

Based on both the clustering and factor analysis methods similar conclusions can be drawn. The most important one is that all individual sources of competitive advantage can be classified in only six groups. The key distinction is between the sources that primarily arise from a firm (i.e. internal sources) and the sources that primarily arise from a firm's environment (i.e. external sources). The internal

11 The basic distinction between the 'Principal Axis Factoring' method and another well-known, i.e. the 'Principal Components Factoring', method is that the 'Principal Axis Factoring' method implicitly assumes that a variable is composed of a common part and a unique part (and the common part is due to the presence of the common factors), whereas the 'Principal Components Factoring' method acknowledges only the common part. The objective of the 'Principal Axis Factoring' method is therefore to first estimate the communalities and then identify the common factors responsible for the communalities and the correlation among the variables. For this reason, most researchers choose to use the 'Principal Axis Factoring' method (Sharma 1996). 
sources can be further divided into tangible and intangible, and employee-related and firm-related. On the other hand, the external sources can be divided into industry-related and national-economy-related. Six groups of sources of a firm's competitive advantage can therefore be defined as follows (also see Figure 1):

Table 2. Rotated factor matrix (for the sources of competitive advantage) based on the 'Principal Axis Factoring' extraction method and the 'Varimax' rotation method

\begin{tabular}{|c|c|c|c|c|c|c|}
\hline \multirow{2}{*}{ Sources of competitive advantage } & \multicolumn{6}{|c|}{ Factors } \\
\hline & 1 & 2 & 3 & 4 & 5 & 6 \\
\hline Transformational capabilities & 0.729 & 0.419 & 0.160 & 0.140 & 0.063 & -0.053 \\
\hline Output-based capabilities & 0.732 & 0.356 & 0.296 & 0.068 & 0.040 & 0.022 \\
\hline Production and R\&D (functional) capabilities & 0.830 & 0.079 & 0.009 & 0.256 & 0.135 & -0.092 \\
\hline Marketing (functional) capabilities & 0.825 & 0.030 & -0.013 & 0.164 & 0.149 & 0.031 \\
\hline Structural capital & 0.643 & 0.497 & 0.249 & 0.094 & 0.126 & 0.127 \\
\hline Tacit knowledge & 0.681 & 0.395 & 0.212 & 0.076 & 0.007 & -0.043 \\
\hline Organisational resources & 0.732 & 0.408 & 0.333 & 0.077 & 0.087 & 0.062 \\
\hline Intangible resources & 0.689 & 0.429 & 0.292 & 0.078 & 0.158 & 0.045 \\
\hline $\begin{array}{l}\text { Exploitation of characteristics of the nationa } \\
\text { economy }\end{array}$ & 0.134 & 0.843 & 0.033 & 0.043 & -0.039 & -0.148 \\
\hline Managerial capabilities & 0.154 & 0.875 & 0.098 & 0.080 & 0.070 & 0.031 \\
\hline Human capital & 0.235 & 0.835 & 0.067 & 0.026 & 0.013 & 0.059 \\
\hline Explicit knowledge & 0.179 & 0.851 & 0.051 & 0.105 & 0.064 & 0.061 \\
\hline Adequate positioning of firm in the industry & 0.249 & 0.694 & 0.133 & 0.149 & -0.069 & 0.026 \\
\hline Active influence on industry forces & 0.177 & 0.672 & 0.161 & 0.135 & 0.031 & -0.056 \\
\hline Exploitation of the industry change & 0.159 & 0.675 & -0.022 & 0.298 & -0.067 & 0.079 \\
\hline Human resources & 0.315 & 0.817 & 0.080 & 0.119 & -0.020 & -0.002 \\
\hline Input-based capabilities & 0.188 & 0.174 & 0.829 & 0.021 & 0.132 & 0.104 \\
\hline HRM (functional) capabilities & 0.161 & 0.180 & 0.819 & 0.058 & 0.220 & 0.051 \\
\hline Purchasing (functional) capabilities & 0.102 & 0.282 & 0.807 & -0.058 & 0.181 & 0.042 \\
\hline Financial (functional) capabilities & 0.131 & 0.114 & 0.825 & 0.013 & 0.186 & 0.014 \\
\hline Physical resources & 0.050 & -0.259 & 0.850 & -0.019 & 0.063 & 0.082 \\
\hline Financial resources & 0.038 & 0.214 & 0.828 & 0.007 & 0.117 & 0.062 \\
\hline
\end{tabular}




\begin{tabular}{|c|c|c|c|c|c|c|}
\hline Tangible resources & 0.179 & 0.254 & 0.801 & 0.054 & 0.159 & 0.025 \\
\hline Positive influence of domestic competition & 0.049 & 0.212 & 0.120 & 0.478 & 0.292 & 0.157 \\
\hline Low threat of substitution & 0.035 & 0.072 & 0.187 & 0.625 & 0.460 & 0.156 \\
\hline Low threat of new entrants & -0.034 & 0.174 & 0.138 & 0.671 & 0.386 & 0.142 \\
\hline Mild rivalry among existing firms in the industry & -0.044 & 0.120 & 0.084 & 0.566 & 0.329 & 0.159 \\
\hline Weak bargaining power of suppliers & 0.011 & 0.039 & 0.167 & 0.445 & 0.533 & 0.299 \\
\hline Weak bargaining power of buyers & -0.030 & 0.227 & 0.230 & 0.380 & 0.522 & 0.189 \\
\hline Quality of domestic factors of production & 0.088 & 0.086 & 0.139 & 0.140 & 0.340 & 0.795 \\
\hline Quality of domestic demand & 0.045 & 0.159 & 0.216 & 0.120 & 0.250 & 0.756 \\
\hline Size of domestic demand & 0.044 & 0.092 & 0.207 & 0.179 & 0.297 & 0.725 \\
\hline Positive influence of related and supporting industries & 0.069 & 0.011 & 0.113 & 0.209 & 0.404 & 0.732 \\
\hline
\end{tabular}

(1) Internal intangible firm-related sources (cluster 1 or factor 1), which mostly include organisational resources, transformational and output-based capabilities, and the knowledge of the firm as a whole.

(2) Internal intangible employee-related sources (cluster 2 or factor 2), which mostly include a firm's strategies, human resources, managerial capabilities, and the knowledge of individuals.

(3) Internal tangible firm-related sources (cluster 3 or factor 3), which mostly include physical and financial resources and input-based and some functional capabilities.

(4) External industry-related (mostly linked with suppliers and buyers) sources (cluster 4 or factor 5), which mostly include variables relating to the weak bargaining power of suppliers and buyers.

(5) External industry-related (mostly linked with the competition) sources (cluster 5 or factor 4), which mostly include variables representing mild rivalry among existing firms in the industry and low threats of substitution and new entrants.

(6) External national-economy-related sources (cluster 6 or factor 6), which mostly include variables representing the characteristics of the national economy.

With regard to the interweaving of the sources of competitive advantage a conclusion can be made that hypothesis 1 should be at least partly confirmed. Perhaps only part confirmation is required since only the sources discussed by the resource-based, capability-based and knowledge-based schools are highly interlaced (clusters and factors 1,2 and 3), while the sources discussed by the industrial organisation school are separated in clusters and factors 4,5 and 6. 
Fig. 1. A proposed classification of the sources of a firm's competitive advantage

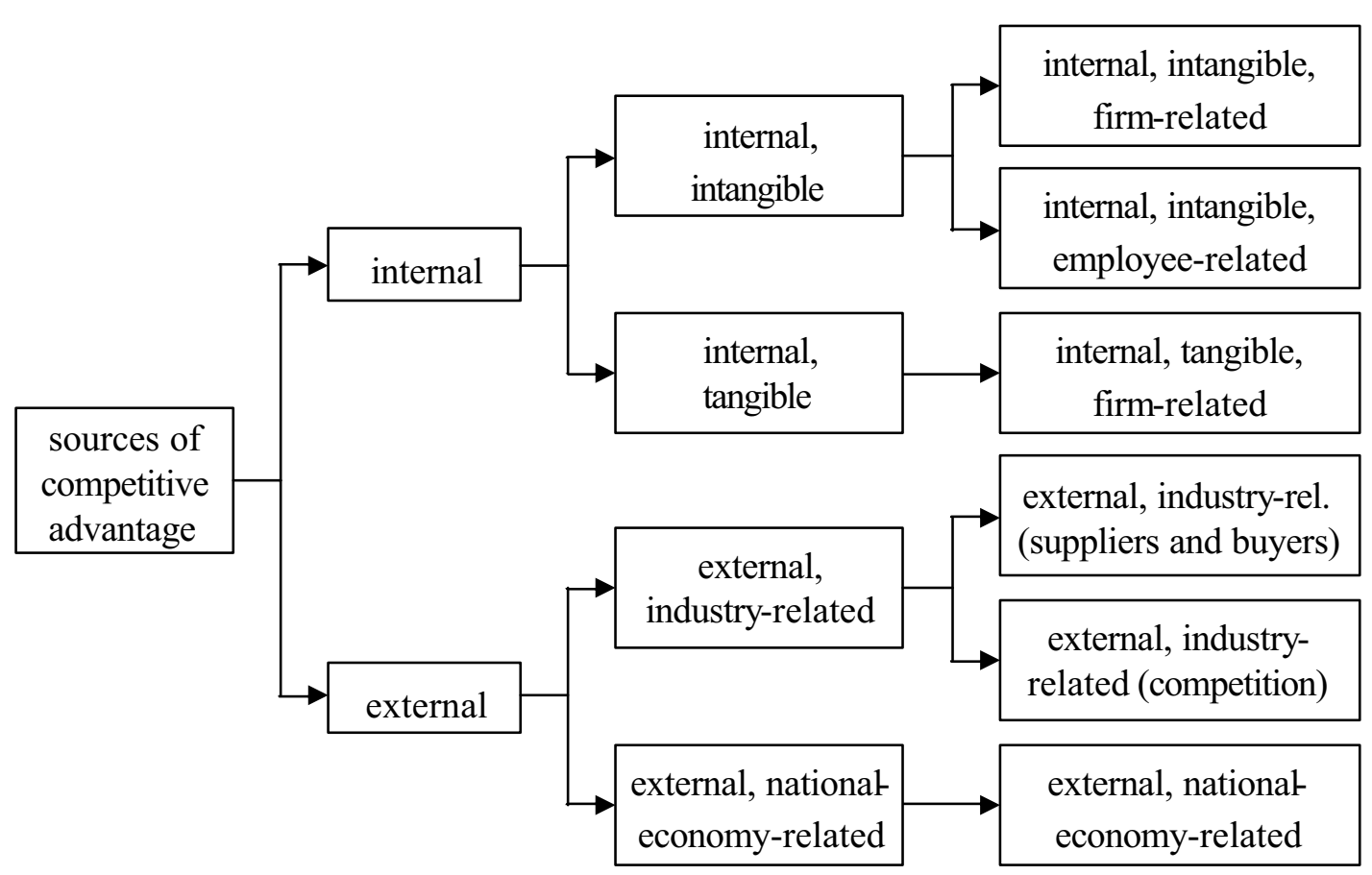

\subsection{Interweaving of a firm's forms of competitive advantage}

Hypothesis 2 is tested by using the same approach as hypothesis 1 . The difference is that hypothesis 2 deals with the interweaving of the forms (and not the sources) of competitive advantage. Based on our goal we again use the clustering method to test hypothesis 2. More specifically, we use the 'WithinGroups Linkage' hierarchical method and Pearson's correlation coefficient as the similarity measure. As shown in Figure A2 and Table A2 (Table A2 is used to explain the variables' codes in Figure A2) in the Appendix, it is reasonable to discuss only two clusters of forms of competitive advantage. The first cluster consists of the variable representing the competitive advantage in lower price (costs), while in the second cluster there are variables relating to the competitive advantage in differentiation.

Table 3. The shares of the explained variance of the forms of competitive advantage and the choice of the adequate number of factors

\begin{tabular}{|c|c|c|c|c|c|c|}
\hline \multirow{2}{*}{ Factor } & \multicolumn{3}{|c|}{ Initial values } & \multicolumn{3}{|c|}{ Extraction sums of squared loadings } \\
\hline & Total & $\%$ of variance & Cumulative $\%$ & Total & $\%$ of variance & Cumulative $\%$ \\
\hline 1 & 13.307 & 88.712 & 88.712 & 13.192 & 87.949 & 87.949 \\
\hline 2 & 0.401 & 2.671 & 91.382 & - & - & - \\
\hline
\end{tabular}


Table 4. Rotated factor matrix (for the forms of competitive advantage) based on the 'Principal Axis Factoring' extraction method and the 'Varimax' rotation method

\begin{tabular}{|l|c|}
\hline Forms of competitive advantage & Factor $\mathbf{1}$ \\
\hline Lower prices in comparison with competitors & 0.791 \\
\hline Differentiation in comparison with competitors & 0.984 \\
\hline Superiority of a product/service & 0.985 \\
\hline Totality of a firm's supply & 0.927 \\
\hline Speed in satisfying customers' needs & 0.932 \\
\hline Flexibility in satisfying customers' needs & 0.946 \\
\hline Positive image of a firm & 0.934 \\
\hline
\end{tabular}

Hypothesis 2 is additionally tested by using factor analysis. Among several possible methods of factor extraction we again use the 'Principal Axis Factoring' method. As shown in Table 3 (column 2), it is reasonable to discuss only one factor behind all forms of competitive advantage. In this case the use of Kaiser's rule is not questionable as the initial eigenvalue at factor 1 is much higher (13.307) and at factor 2 much lower (0.401) than 1.

The factor matrix (here we do not deal with the rotated factor matrix as we only have one factor) for the most important forms of competitive advantage is shown in Table 4. The results reveal that all forms of differentiation advantage have high loadings on the factor, whereas the price advantage has a somewhat lower loading on the factor. This means that behind all forms of competitive advantage there is probably only one factor - let us call it the 'superior position of a firm in the market in comparison with the most important competitors' - although this factor is more closely related with the differentiation advantage than the price advantage.

What can we conclude about hypothesis 2 ? Based on the clustering method we cannot reach an unequivocal conclusion. At best there seem to be two clusters of variables, i.e. the price advantage and the differentiation advantage, although such a conclusion is pretty risky given the relatively short distance between both clusters. On the other hand, the results based on the factor analysis are somewhat clearer. They indicate that behind all forms of competitive advantage there is probably only one factor, i.e. a certain superior position of a firm in the market. This brings us to the conclusion that the forms of competitive advantage are in no small measure interwoven, meaning that hypothesis 2 can be confirmed. 


\section{Discussion and conclusion}

By using the clustering and factor analysis methods we found that the sources (discussed within different schools) and forms of competitive advantage do in fact interweave. Based on this, we need to ask ourselves whether a redefinition of the existing concepts is required or not.

Before answering this question we briefly discuss three key differences among the four schools about the sources of a firm's competitive advantage (see Figure 2). Perhaps the most important difference lies in the logic of creating a competitive advantage. While the resource-based, capability-based and knowledge-based schools believe a competitive advantage primarily takes its source in the firm (the so-called 'inside-out' view), the industrial organisation school believes that a competitive advantage has its origin in a firm's environment, mostly in the structure of its industry (the so-called 'outside-in' view) (Barney 1991).

The second difference among the schools relates to the organisational level at which the sources of competitive advantage are discussed. While the industrial organisation and resource-based schools discuss the sources at the strategic business unit level (Wernerfelt 1984; Porter 1985; Peteraf 1993; Pucko 2002a; Pucko 2002b), the capability-based and knowledge-based schools discuss them at the corporate level (Stalk et al. 1992; Tampoe 1994; Quinn et al. 1996; Wiig 1997; Pucko 2002a; Pucko 2002b).

The third difference among the schools lies in their breadth. What we have in mind here is the differences between the resource-based, capability-based and knowledge-based schools. While the knowledge-based school believes that the only source of competitive advantage is knowledge, the capability-based school believes that a competitive advantage can also be built on some other capabilities besides knowledge. Similarly, the resource-based school defines the potential sources of competitive advantage even more widely. It believes that competitive advantage can be built on knowledge, capabilities and some other resources of a firm that cannot be classified as either knowledge or capabilities. Some authors believe that the difference in their width is the most important reason why these three schools differ in their relevance (Javidan 1998).

Following our detailed empirical analysis and brief overview of the differences between the four schools we need to discuss the theoretical implications of our findings. We believe that each of the four schools, as long as it is discussed separately, represents a logical explanation of the formation of competitive advantage. Further, all schools have at least limited empirical support (Cater 2003). 
Fig. 2. The comparison of four schools of thought

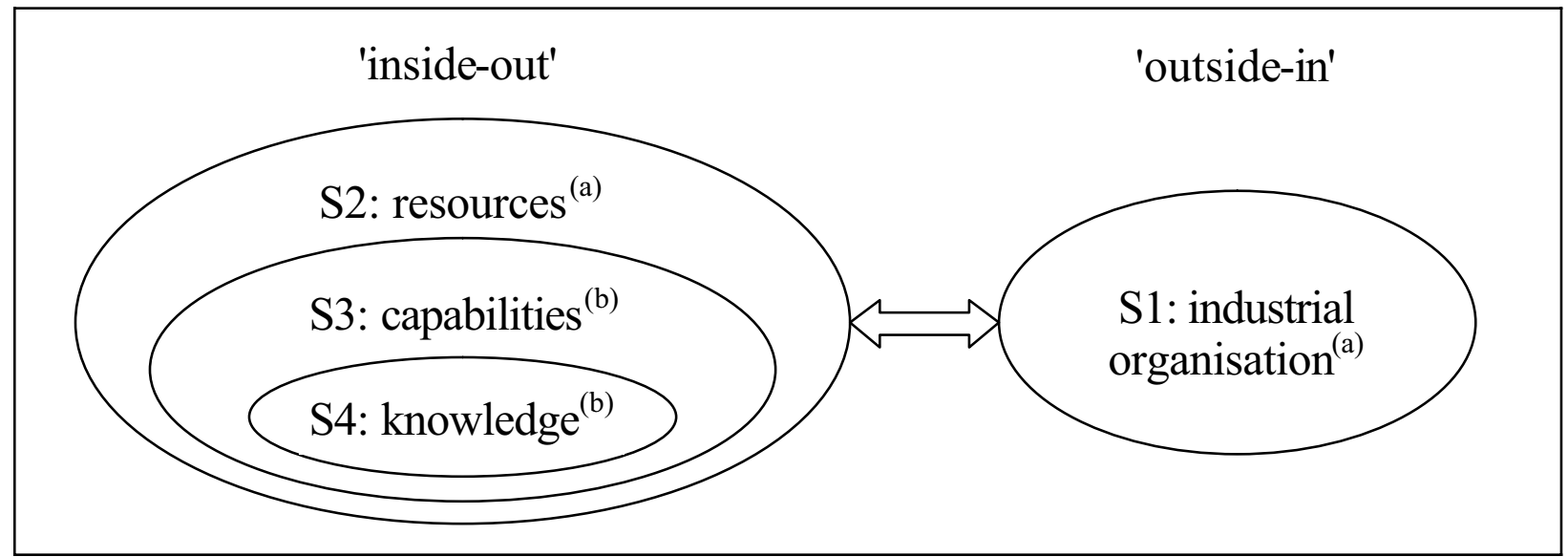

a) The sources of competitive advantage are discussed on the strategic business unit level.

b) The sources of competitive advantage are discussed on the corporate level.

However, when the four schools are compared and analysed simultaneously we cannot avoid the feeling that a redefinition of the existing concepts is needed. By using the clustering and factor analysis methods we discovered some common characteristics of the resource-based, capability-based and knowledge-based schools. This demonstrates that these schools are not in conflict. In addition, they are complementary and also partly substitutional to each other (Makadok 2001), which has led some authors to propose the fusion of research on resources, capabilities and knowledge (Mahoney 1995) and even the merger of the three schools within one large 'internal' school (Kamoche 1993; Kamoche 1996; Makadok 2001). Obviously, the similarity among these schools, i.e. the fact they all represent the 'inside-out' view outweighs the differences between them, i.e. different width and different organisational levels at which the sources of competitive advantage are discussed.

If the resource-based, capability-based and knowledge-based schools were to be redefined the three following questions should be answered:

(a) What should the new school be called? Of several possible answers, these three seem most acceptable:

(b) Internal school: this name clearly emphasises the internal nature of the sources although, on the other hand, information about which sources we are discussing is lost.

(c) Resource-capability-knowledge-based school: this name emphasises the synthesis of three similar schools. Although very descriptive, it may be too long and impractical.

(d) Resource-based school: this name is simple and practical but also somewhat misleading. If this name is used, additional elucidation about which type of resources are most relevant would be needed. 
(e) At which organisational level (strategic business unit or corporation) should the sources be primarily treated? Despite the different views in the scientific literature, numerous examples of firms show that competitive advantage can take its source in a certain resource used by a single strategic business unit as well as in the (core) capability of a corporation as a whole. The internal school should therefore tolerate discussion of the sources of competitive advantage at both organisational levels, which means that it has to be closely linked to business and corporate level strategies.

(f) How should the internal sources be classified? If we accept the proposed synthesis of the resource-based, capability-based and knowledge-based schools, classification of the internal sources of competitive advantage as presented in the theoretical part of this paper becomes inappropriate. Instead, the internal sources should be classified as proposed in Figure 1.

Following the above discussion critics might say that our attempt to propose a redefinition of the existing 'internal' schools based on the applied methodology, i.e. by using the variables that represent the sources of competitive advantage and mostly disregard different methodological backgrounds of each individual school, is too ambitious. In fact, we can partly even agree with them. At the same time, however, we believe that the proposed redefinition, which is based not only on our results but also on the discussion of several other authors (Mahoney 1995; Kamoche 1996; Makadok 2001), still makes sense and is much needed. Although the three schools have been developed in different circumstances (contexts) and by using different methodologies, this does not mean that these circumstances are still equally present and relevant today. In other words, our conclusion focuses strictly on present situation and not on the past one. For instance, nowadays physical resources are no longer as relevant as they used to be in the 1950s when the resource-based school was introduced. A redefinition of the existing schools is therefore needed because some sources that used to be relevant in the past (and based on which the discussed schools have been developed) are no longer relevant today.

Our suggestion therefore needs to be understood not as an attempt to blur or even erase the differences because of which these schools have been discussed separately but rather in the light of the unreasonableness to continue with the discussion of similar things in the literature under different titles (i.e. different schools). For example, even the advocates of the resource-based school agree that tangible resources are much less relevant for the creation of competitive advantage than intangible ones. And what are capabilities and knowledge if not intangible resources? Does not this mean that resource-based, capability-based and knowledge-based schools are slowly flowing into one another? Therefore, should not these three schools be redefined or even merged within one 'internal' school? 
If we agree with the proposed redefinition of the resource-based, capabilitybased and knowledge-based schools, the relationship between the new internal school and the external (i.e. industrial organisation) school needs to be analysed. Based on our findings we can definitely say that both schools are sufficiently different to conclude that we are dealing with two separate schools. In other words, we have two completely different and competitive approaches. While the internal school follows the 'inside-out' logic, the external school follows the 'outside-in' logic.

With reference to the difference between the 'inside-out' and 'outside-in' approaches, there are several empirical studies that seek to find out which sources of competitive advantage - internal or external - are more relevant. Most of these studies show that, although both groups of sources have a statistically significant influence on a firm's performance (Spanos/Lioukas 2001), internal sources seem to be even more important (i.e. they explain relatively larger portions of the variance in different performance indicators). These studies report the following proportions between the variances explained by internal and external sources: $45.8 \%$ vs. $4.0 \%$ (Rumelt 1991), $36.9 \% \quad$ vs. $6.2 \%$ (Mauri/Michaels 1998), 55.0\% vs. 10.2\% (Roquebert et al. 1996), 37.8\% vs. 18.5\% (Hansen/Wernerfelt 1989), and 36.0\% vs. 18.7\% (McGahan/Porter 1997), all in favour of internal sources. Similar results are also reported by Barney (1986), Powell (1993) and Maijoor and Van Witteloostuijn (1996), while only a few studies give priority to external sources (see, for example, Kotha and Nair (1995)).

Although the internal sources of competitive advantage seem more relevant in explaining the origins of competitive advantage we should still not completely forget about the external sources. In other words, the relationship between the internal and external schools should not be seen as solely competitive but also complementary. Complementarity is particularly found in the need to discuss the internal and external sources of competitive advantage simultaneously (Powell 1992; Verdin/Williamson 1992; Verdin/Williamson 1993; Oktemgil 1994; Gadhoum 1998; Spanos/Lioukas 2001) as it is obvious that the mystery of creating a competitive advantage cannot be explained by any one school alone. On the contrary, each of them can contribute its own (albeit small) part to explaining the competitive advantage phenomenon. In this respect, several authors strive for more friendly relations between the advocates of both schools. Verdin and Williamson (1993), for instance, mention that the debate between the two schools is often a 'dialogue of the deaf'.

They condemn such behaviour of both sides' advocates and argue that there are important payoffs to be gained by linking and integrating the two views. Foss (1996) on the other hand talks about 'balanced pluralism' as a new approach to strategic management that involves a moderate 'import' of economics into the conversation of business researchers. This means that both schools should remain open to new and different ideas. The need for complementarity between 
both approaches is also emphasised by many other authors (see, for instance, Mauri/Michaels 1998; Spanos/Lioukas 2001).

While our empirical results enable us (at least from the discussed perspective) to start a discussion on the need for a redefinition of the existing concepts regarding the sources of competitive advantage, the results regarding the forms of competitive advantage are not so definite. In spite of this, we can say that there are some indications that support Porter's (1985) idea of two types of competitive advantage, i.e. lower price (cost) and differentiation, although strictly empirically such a conclusion is not supported by statistically significant results. On the other hand, we are able to conclude that a firm can have a simultaneous price (cost) and differentiation advantage, which means we can agree with some other authors who argue that a firm can both sides offer a differentiated product at a lower price (Flynn et al. 1995; Flynn/Flynn 1996).

The question that needs to be answered before reaching a final conclusion is also how might the empirical results be influenced by the fact that the study was carried out in the post-transitional Slovenian business environment. We believe that the answer here is twofold. On one hand, the conclusions regarding the sources of competitive advantage are very similar to conclusions of the studies (although few in number) carried out in the established market economies (Mahoney 1995; Kamoche 1996; Makadok 2001). In this respect, the specific Slovenian context of our study therefore did not have a significant influence on the empirical results. On the other hand, however, the results regarding the forms of competitive advantage are somewhat specific.

The fact that no clear distinction between two basic forms of competitive advantage have been discovered and that many firms tried to compete on lower price (costs) and differentiation at the same time could be the consequence of firms' indecision regarding the strategic choices they make. One possible explanation for this can of course be found in Slovenian firm's relative inexperience with the market economy as well as in other challenges Slovenian firms were preoccupied with during the transition period (radical restructuring, search for new markets etc.).

Based on the interweaving of the sources and forms of competitive advantage we feel confident in concluding that a careful and gradual redefinition ${ }^{12}$ of the existing concepts is required, which means that hypothesis 3 can be confirmed. The intense interweaving of the sources and forms of competitive advantage makes the process of competition among firms (i.e. the process that starts in the sources of competitive advantage, continues in the forms of competitive

12 By 'careful' and 'gradual' redefinition we mean that additional and much more complex studies (i.e. studies that also consider other aspects of the existing four schools) should be carried out before a wide consensus regarding the proposed redefinition of the existing teachings can be reached. 
advantage and ends in more or less successful firm performance) very complex. For this reason, the complexity of creating a competitive advantage cannot be explained by any one school alone. We need to simultaneously pay attention to at least two different approaches (i.e. 'inside-out' and 'outside-in') because each can contribute its own part to explaining the mystery of competitive advantage. Based on the above discussion, the paper's main conclusion is perhaps best (albeit in a very simplified way) depicted in Figure 3.

Fig. 3. Explaining the origins of a firm's competitive advantage based on the complementarity of the internal and external sources (schools of thought)

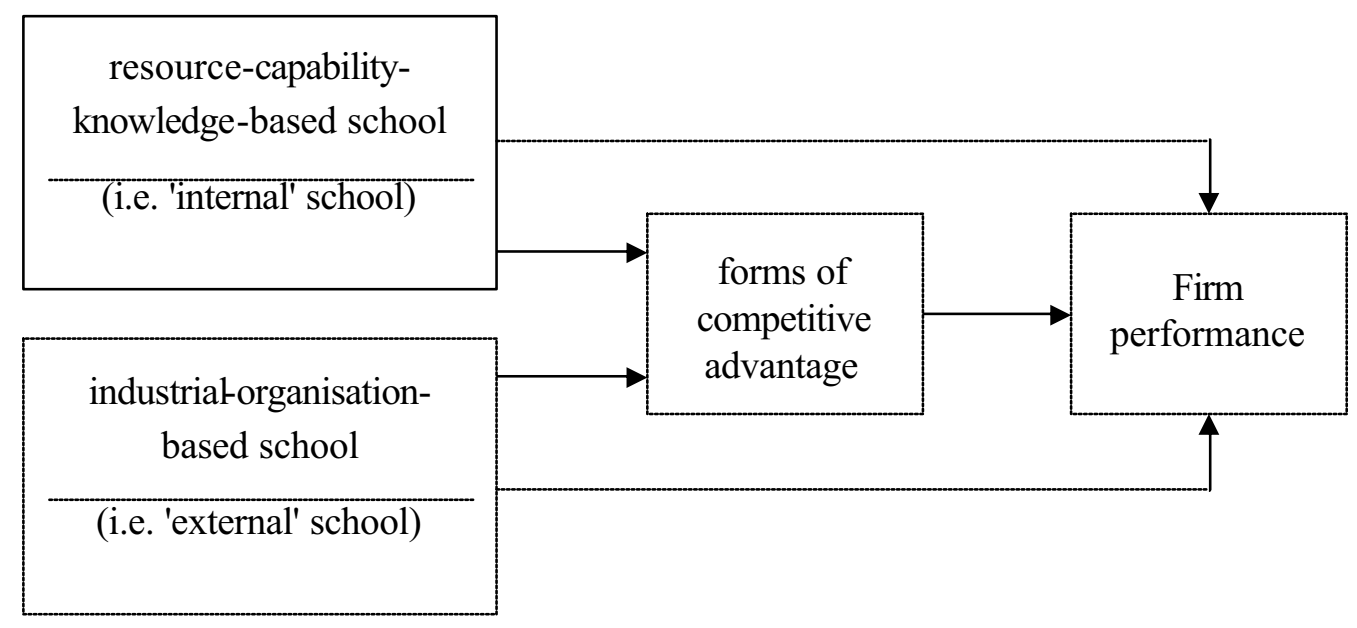

Our findings unfortunately cannot be adequately compared with the findings of similar empirical studies on the sources and forms of competitive advantage, as similar studies (in transitional economies as well as in established market economies) are very few in number. In this respect, we dare hope that our research is considered a kind of introduction to a more detailed discussion on the interweaving of the sources and forms of competitive advantage, as well as a contribution to the existing discussion on the need for a redefinition of the existing concepts.

Irrespective of all the findings of this research, its possible weaknesses should also be mentioned. Perhaps the most important weakness lies in the fact that real sources of competitive advantage are usually well hidden, making it impossible for a researcher to measure them completely objectively. For this reason, we had to use managers' relatively subjective assessments of the basic sources and forms of competitive (dis)advantage of their firms. In future research this weakness might be partially avoided by personally interviewing managers, by observing each firm over a longer period of time and/or by combining the results of quantitative and qualitative studies. In this respect, especially (multiple) case studies as a methodological approach might be useful. Another possible weakness of this research is the use of stratified sampling, which was necessary 
because of the broader goals of the research. The consequence of stratified sampling is that the sample is not completely representative, meaning the conclusions cannot be automatically extrapolated for all Slovenian firms.

As a suggestion for further research, we believe that similar studies should also be carried out on a much more homogeneous sample of firms. This would, of course, limit the 'applicable value' of each research only to that small homogeneous group of firms but over a longer period of time several similar studies might give additional insights into the true origins of a firm's competitive advantage. Finally, additional empirical evidence on this important aspect of strategic management should also be based on a longitudinal study, if possible carried out on a large international sample of firms. In spite of these weaknesses, we still believe the research has the potential to broaden our knowledge in the field of firm competitiveness. Its most important advantage is probably the relatively large sample of firms involved, which has allowed us to draw certain conclusions with minimum risk.

\section{References}

Bain, J.S. (1956): Barriers to New Competition: Their Character and Consequences in Manufacturing Industries, Cambridge: Harvard University Press.

Bamberger, I. (1989): Developing Competitive Advantage in Small and Medium-Size Firms, in: Long Range Planning, 22, 5, 80-88.

Barney, J.B. (1986): Strategic Factor Markets: Expectations, Luck and Business Strategy, in: Management Science, 32, 10, 1231-1241.

Barney, J.B. (1991): Firm Resources and Sustained Competitive Advantage, in: Journal of Management, 17, 1, 99-120.

Barney, J.B. (1996): The Resource-Based Theory of the Firm, in: Organisation Science, 7, 5, 469.

Barney, J.B. (1997): Gaining and Sustaining Competitive Advantage, Reading: Addison-Wesley.

Bartmess, A./Cerny, K. (1993): Building Competitive Advantage through a Global Network of Capabilities, in: California Management Review, 35, 2, 78-103.

Bharadwaj, S.G./Varadarajan, R.P./Fahy, J. (1993): Sustainable Competitive Advantage in Service Industries: A Conceptual Model and Research Propositions, in: Journal of Marketing, 57, 4, 83-99.

Collis, D.J. (1991): Organisational Capability as a Source of Profit: Working Paper, Boston: Harvard Business School.

Collis, D.J. (1994): How Valuable Are Organisational Capabilities?, in: Strategic Management Journal, 15, Winter Special Issue, 143-152.

Cater, T. (2001a): Hipoteze o osnovah konkurencne prednosti podjetja, in: Organizacija, 34, 2, 6474.

Cater, T. (2001b): Knowledge Management as a Means of Developing a Firm's Competitive Advantage, in: Management, 6, 1-2, 133-153. 
Cater, T. (2001c): Management znanja kot pripomocek za razvijanje konkurencne prednosti podjetja, in: IB revija, 35, 1, 76-85.

Cater, T. (2003): Osnove konkurencnih prednosti slovenskih podjetij: Doktorska disertacija, Ljubljana: Ekonomska fakulteta.

Day, G.S. (1994): The Capabilities of Market-Driven Organizations, in: Journal of Marketing, 58, 4, $37-52$.

Demarest, M. (1997): Understanding Knowledge Management, in: Long Range Planning, 30, 3, 374-384.

Edvinsson, L. (1997): Developing Intellectual Capital at Scandia, in: Long Range Planning, 30, 3, 366-373.

Edvinsson, L./Malone, M.S. (1997): Intellectual Capital: The Proven Way to Establish Your Company's Real Value by Measuring Its Hidden Brainpower, London: Piatkus.

Edvinsson, L./Sullivan, P. (1996): Developing a Model for Managing Intellectual Capital, in: European Management Journal, 14, 4, 356-364.

Eisenhardt, K.M./Martin, J.A. (2000): Dynamic Capabilities: What Are They?, in: Strategic Management Journal, 21, 10-11, 1105-1121.

Flynn, B.B./Schroeder, R.G./Sakakibara, S. (1995): The Impact of Quality Management Practices on Performance and Competitive Advantage, in: Decision Sciences, 26, 5, 659-691.

Flynn, J. E./Flynn, B.B. (1996): Achieving Simultaneous Cost and Differentiation Competitive Advantages through Continuous Improvement: World Class Manufacturing as a Competitive Strategy, in: Journal of Managerial Issues, 8, 3, 360-379.

Foss, N.J. (1996): Research in Strategy, Economics, and Michael Porter, in: Journal of Management Studies, 33, 1, 1-24.

Gadhoum, Y. (1998): Corporate Governance and Top Managers: Potential Sources of Sustainable Competitive Advantage, in: Human Systems Management, 17, 3, 205-222.

Gospodarski vestnik (2002): FIPO baza 2002 [URL: http://www.gvin.com/fipo2002].

Hansen, G.S./Wernerfelt, B. (1989): Determinants of Firm Performance: The Relative Importance of Economic and Organisational Factors, in: Strategic Management Journal, 10, 5, 399-411.

Helms, M.M./Ettkin, L.P. (2000): Time-Based Competitiveness: A Strategic Perspective, in: Competitiveness Review, 10, 2, 1-14.

Hitt, M.A./Ireland, D.R. (1985): Corporate Distinctive Competence, Strategy, Industry and Performance, in: Strategic Management Journal, 6, 3, 273-293.

Hunt, S.D. (1999): The Strategic Imperative and Sustainable Competitive Advantage: Public Policy Implications of Resource-Advantage Theory, in: Journal of the Academy of Marketing Science, 27, 2, 144-159.

Inkpen, A.C. (1998): Learning and Knowledge Acquisition through International Strategic Alliances, in: Academy of Management Executive, 12, 4, 69-80.

Javidan, M. (1998): Core Competence: What Does It Mean in Practice?, in: Long Range Planning, $31,1,60-71$.

Kamoche, K. (1993): Strategic Human Resource Management within a Resource-Capability View of the Firm: Working Paper, Birmingham: Birmingham Business School. 
Kamoche, K. (1996): Strategic Human Resource Management within a Resource-Capability View of the Firm, in: Journal of Management Studies, 33, 2, 213-233.

Karnani, A. (1984): Generic Competitive Strategies: An Analytical Approach, in: Strategic Management Journal, 5, 4, 367-380.

King, A.W./Fowler, S.W./Zeithaml, C. P. (2001): Managing Organisational Competencies for Competitive Advantage: The Middle-Management Edge, in: Academy of Management Executive, 15, 2, 95-106.

Kotha, S./Nair, A. (1995): Strategy and Environment as Determinants of Performance: Evidence from the Japanese Machine Tool Industry, in: Strategic Management Journal, 16, 7, 497518 .

Kotha, S./Vadlamani, B.L. (1995): Assessing Generic Strategies: An Empirical Investigation of Two Competing Typologies in Discrete Manufacturing Industries, in: Strategic Management Journal, 16, 1, 75-83.

Lado, A.A./Boyd, N.G./Wright, P. (1992): A Competency-Based Model of Sustainable Competitive Advantage: Toward a Conceptual Integration, in: Journal of Management, 18, $1,77-91$.

Lank, E. (1997): Leveraging Invisible Assets: The Human Factor, in: Long Range Planning, 30, 3, 406-412.

Leonard, D./Sensiper, S. (1998): The Role of Tacit Knowledge in Group Innovation, in: California Management Review, 40, 3, 112-132.

Leonard-Barton, D. (1992): Core Capabilities and Core Rigidities: A Paradox in Managing New Product Development, in: Strategic Management Journal, 13, Summer Special Issue, 111125.

Luo, Y. (2000): Dynamic Capabilities in International Expansion, in: Journal of World Business, 35, 4, 355-378.

Ma, H. (2000): Of Competitive Advantage: Kinetic and Positional, in: Business Horizons, 43, 1, 5364.

Mahoney, J.T. (1995): The Management of Resources and the Resource of Management, in: Journal of Business Research, 33, 2, 91-101.

Mahoney, J.T./Pandian, R.J. (1992): The Resource-Based View within the Conversation of Strategic Management, in: Strategic Management Journal, 13, 5, 363-380.

Maijoor, S./Van Witteloostuijn, A. (1996): An Empirical Test of the Resource-Based Theory: Strategic Regulation in the Dutch Audit Industry, in: Strategic Management Journal, 17, 7, 549-569.

Makadok, R. (2001): Toward a Synthesis of the Resource-Based and Dynamic-Capability Views of Rent Creation, in: Strategic Management Journal, 22, 5, 387-401.

Mason, E.S. (1939): Price and Production Policies of Large-Scale Enterprises, in: American Economic Review, 29, 3, 61-74.

Mauri, A.J./Michaels, M.P. (1998): Firm and Industry Effects within Strategic Management: An Empirical Examination, in: Strategic Management Journal, 19, 3, 211-219. 
McAulay, L./Russell, G./Sims, J. (1997): Tacit Knowledge for Competitive Advantage, in: Management Accounting, 75, 11, 36-37.

McGahan, A.M./Porter, M.E. (1997): How Much Does Industry Matter, Really?, in: Strategic Management Journal, 18, Summer Special Issue, 15-30.

Michalisin, M. D./Smith, R.D./Kline, D.M. (1997): In Search of Strategic Assets, in: International Journal of Organisational Analysis, 5, 4, 360-387.

Nonaka, I./Takeuchi, H. (1995): The Knowledge-Creating Company: How Japanese Companies Create the Dynamics of Innovation, Oxford: Oxford University Press.

Oktemgil, M. (1994): Model Building on Resource Management Capability as a Rent Earning Potential for Sustainable Competitive Advantage: Working Paper, Birmingham: Birmingham Business School.

Penrose, E.T. (1959): The Theory of the Growth of the Firm, New York: M. E. Sharpe.

Peteraf, M.A. (1993): The Cornerstones of Competitive Advantage: A Resource-Based View, in: Strategic Management Journal, 14, 3, 179-191.

Porter, M.E. (1979): How Competitive Forces Shape Strategy, in: Harvard Business Review, 57, 2, 137-145.

Porter, M.E. (1980): Competitive Strategy: Techniques for Analyzing Industries and Competitors, New York: Free Press.

Porter, M.E. (1981): The Contributions of Industrial Organisation to Strategic Management, in: Academy of Management Review, 6, 4, 609-620.

Porter, M.E. (1985): Competitive Advantage: Creating and Sustaining Superior Performance, New York: Free Press.

Porter, M.E. (1990): The Competitive Advantage of Nations, New York: Free Press.

Post, H.A. (1997): Building a Strategy on Competences, in: Long Range Planning, 30, 5, 733-740.

Powell, T.C. (1992): Organisational Alignment as Competitive Advantage, in: Strategic Management Journal, 13, 2, 119-134.

Powell, T.C. (1993): Administrative Skill as Competitive Advantage - Extending Porter's Analytical Framework, in: Canadian Journal of Administrative Sciences, 10, 2, 141-153.

Prahalad, C.K./Hamel, G. (1990): The Core Competence of the Corporation, in: Harvard Business Review, 68, 5-6, 79-93.

Prescott, E.C./Visscher, M. (1980): Organisational Capital, in: Journal of Political Economy, 88, 3, 446-461.

Pucko, D. (1998): Poslovodenje znanja in vplivi na strateško poslovodenje ter analizo, in: Organizacija, 31, 10, 557-565.

Pucko, D. (2002a): Analiza konkurencnih prednosti slovenskih podjetij, in: Prašnikar, J. (ed.): Primerjajmo se z najboljšimi, Ljubljana: Finance, 175-195.

Pucko, D. (2002b): Sources of Competitive Advantage of the Business Firms in Transforming Economies: Case of Slovenia, in: An Enterprise Odyssey: Economics and Business in the New Millenium, Zagreb, 27-29 June 2002, Zagreb: Graduate School of Economics and Business, 1385-1403. 
Quinn, J.B./Anderson, P./Finkelstein, S. (1996): Managing Professional Intellect: Making Most of the Best, in: Harvard Business Review, 74, 2, 71-80.

Roquebert, J.A./Phillips, R.L./Westfall, P.A. (1996): Markets vs. Management: What 'Drives' Profitability?, in: Strategic Management Journal, 17, 8, 653-664.

Rumelt, R.P. (1991): How Much Does Industry Matter?, in: Strategic Management Journal, 12, 3, 167-185.

Sashi, C.M./Stern, L.W. (1995): Product Differentiation and Market Performance in Producer Goods Industries, in: Journal of Business Research, 33, 2, 115-127.

Sharma, S. (1996): Applied Multivariate Techniques, New York: John Wiley \& Sons.

Snow, C.C./Hrebiniak, L.G. (1980): Strategy, Distinctive Competence, and Organisational Performance, in: Administrative Science Quarterly, 25, 2, 317-336.

Spanos, Y.E./Lioukas, S. (2001): An Examination into the Causal Logic of Rent Generation: Contrasting Porter's Competitive Strategy Framework and the Resource-Based Perspective, in: Strategic Management Journal, 22, 10, 907-934.

Stalk, G./Evans, P./Shulman, L.E. (1992): Competing on Capabilities: The New Rules of Corporate Strategy, in: Harvard Business Review, 70, 4, 57-69.

Statistical Yearbook of the Republic of Slovenia (2002): Ljubljana: Statistical Office of the Republic of Slovenia.

Tampoe, M. (1994): Exploiting the Core Competences of Your Organisation, in: Long Range Planning, 27, 4, 66-77.

Teece, D.J. (1998): Capturing Value from Knowledge Assets: The New Economy, Markets for Know-How, and Intangible Assets, in: California Management Review, 40, 3, 55-79.

Ulrich, D. (1987): Organisational Capability as a Competitive Advantage: Human Resource Professionals as Strategic Partners, in: Human Resource Planning, 10, 4, 169-184.

Verdin, P.J./Williamson, P.J. (1992): Core Competence, Competitive Advantage and Industry Structure: Working Paper, Fontainebleau: INSEAD.

Verdin, P.J./Williamson, P.J. (1993): Core Competence, Competitive Advantage and Market Analysis: Working Paper, Fontainebleau: INSEAD.

Wernerfelt, B. (1984): A Resource-Based View of the Firm, in: Strategic Management Journal, 5, 2, 171-180.

Whitehill, M. (1997): Knowledge-Based Strategy to Deliver Sustained Competitive Advantage, in: Long Range Planning, 30, 4, 621-627.

Wiig, K.M. (1997): Integrating Intellectual Capital and Knowledge Management, in: Long Range Planning, 30, 3, 399-405.

Zack, M.H. (1999): Developing a Knowledge Strategy, in: California Management Review, 41, 3, 125-145.

Zakon o gospodarskih družbah (ZGD-F) (2001): Ljubljana: Uradni list RS 45/01.

Zupan, N. (1996): Human Resources as a Source of Competitive Advantage in Transitional Companies: The Case of Slovenia, in: Slovenska ekonomska revija, 47, 5-6, 510-524. 
Structural parameters of the industry (C5)

- low threat of substitution

- low threat of new entrants

- mild rivalry among existing firms in the

industry

Structural parameters of the industry (C4):

- weak bargaining power of suppliers

- weak bargaining power of buyers

Resources and capabilities (C3):

- physical resources

- financial resources

- input-based capabilities

- some functional capabilities

Strategies, capabilities and knowledge (C2):

- strategies (response to the ext. challenges)

- human resources

- managerial capabilities

- knowledge of individuals (human capital)

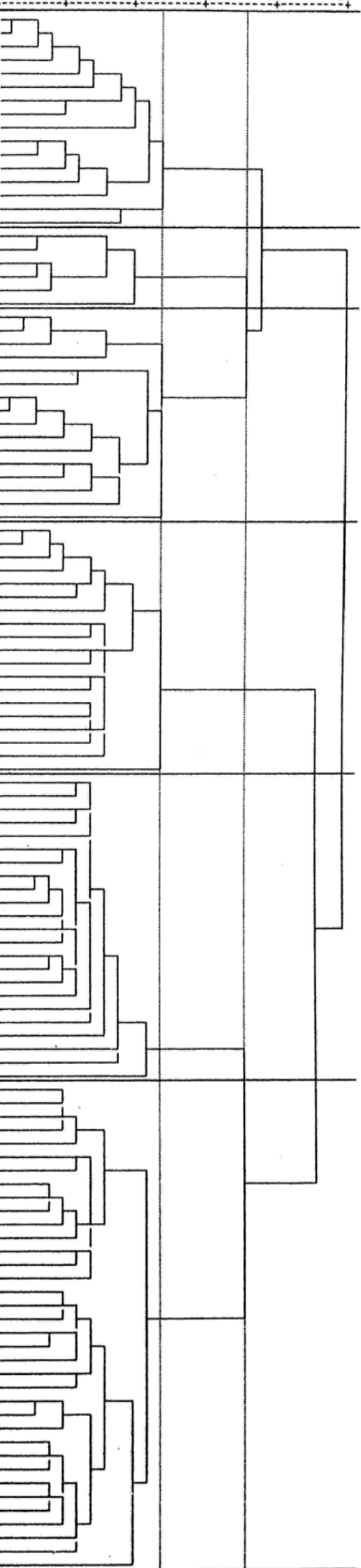


Table A1. Proposed classification of the sources of a firm's competitive advantage (description of the variables in Figure A1)

\begin{tabular}{|c|c|}
\hline & $\begin{array}{l}\text { V307-H = systemic knowledge; V307-I = (self)motivated creativity; V307-J = knowledge } \\
\text { about knowledge management; V307-L = knowledge based on strategic alliances; V702-A4 } \\
=\text { information technology; V302-C3 = ability to create a positive organisational culture; V302- } \\
\mathrm{C} 4=\text { ability to fully utilise a firm's (production) capacities; V702-D13 = intellectual property; } \\
\text { V702-D14 = information systems and databases; V702-D6 = relationships within a firm; } \\
\text { V702-D7 = firm-environmental relationships; V702-D12 = brands; V302-G = production and } \\
\text { R\&D (functional) capabilities; V302-H = marketing (functional) capabilities; V302-D3 = } \\
\text { beneficial environmental effects; V302-C = transformational capabilities; V302-C2 = } \\
\text { organisational learning; V302-A6 = ability to respond quickly to environmental challenges; } \\
\text { V307-B = structural capital; V307-B1 = organisational capital; V302-C1 = ability of } \\
\text { innovation and entrepreneurship; V307-B2 = customer capital; V307-C = tacit knowledge; } \\
\text { V702-D8 = a firm's image (reputation); V702-D9 = partners' and customers' trust; V702-D5 } \\
=\text { organisational culture; V307-K = technological knowledge (know-how); V307-M = } \\
\text { experience; V302-D4 = ability to develop and preserve a high level of customer loyalty; } \\
\text { V302-D = output-based capabilities; V702-D = organisational resources; V702-F = intangible } \\
\text { resources; V302-D5 = ability to react flexibly; V302-A5 = ability to enact a beneficial firm- } \\
\text { environmental relationship; V302-D1 = ability of developing new and improving old } \\
\text { products/services; V302-C5 = ability to master the production of core products. }\end{array}$ \\
\hline & $\begin{array}{l}\text { V307-F = conceptual knowledge; V702-D4 = organisational structure; V302-A2 = managers' } \\
\text { capability of organising; V302-A4 = managers' capability of controlling; V702-C = human } \\
\text { resources; V307-A = human capital; V307-E = team knowledge; V702-C3 = qualified } \\
\text { professionals/experts; V702-D1 = system of planning; V702-C4 = qualified managers; V307- } \\
\mathrm{G}=\text { applicable knowledge; V307-D = explicit knowledge; V702-D2 = system of leadership; } \\
\text { V302-A = managerial capabilities; V302-A3 = managers' capability of leadership; V302-A1 = } \\
\text { managers' capability of planning; V702-C2 = qualified workers/employees; V702-D3 = } \\
\text { system of controlling; V301-H = exploitation of characteristics of the national economy; V701- } \\
\text { F = adequate positioning of firm in the industry; V701-H = exploitation of the industry change; } \\
\text { V701-G = active influence on industry forces; V301-E = positive influence of domestic } \\
\text { competition. }\end{array}$ \\
\hline & $\begin{array}{l}\text { V702-A = physical resources; V702-A2 = buildings and infrastructure; V702-A1 = land and } \\
\text { geographical location; V702-C1 = cheap labour; V702-A3 = traditional technology; V702-B1 } \\
\text { = access to sufficient financial resources; V702-D10 = market share; V302-B1 = ability to } \\
\text { assure sufficient and quality resources; V302-B2 = ability to operate with minimal stocks of } \\
\text { material; V302-E = HRM (functional) capabilities; V302-I = financial (functional) capabilities; } \\
\text { V702-B = financial resources; V702-D11 = ISO standards; V302-B = input-based } \\
\text { capabilities; V702-E = tangible resources; V302-D2 = ability to offer a wide variety of } \\
\text { products/services in the broad market; V302-F = purchasing (functional) capabilities; V702- } \\
\text { B2 = access to financial resources on favourable terms; V701-E = mild rivalry among existing } \\
\text { firms in the industry. }\end{array}$ \\
\hline
\end{tabular}




\begin{tabular}{|c|c|}
\hline & $\begin{array}{l}\text { V701-B2 = highly differentiated products/services in the industry; 701-B3 = great significance } \\
\text { of products/services for buyers; V701-B = weak bargaining power of buyers; V701-A6 = } \\
\text { suppliers depend on the firm; V302-B3 = great bargaining power of the firm relative to the } \\
\text { bargaining power of suppliers; V701-A = weak bargaining power of suppliers; V302-D6 = } \\
\text { great bargaining power of the firm relative to the bargaining power of buyers; V701-B5 = high } \\
\text { switching costs for buyers; V701-B1 = large number of buyers; V701-B6 = the firm does not } \\
\text { depend on a few strong buyers; V701-A2 = undifferentiated suppliers' material and services; } \\
\text { V701-A3 = independence of suppliers' material and services; V701-A4 = existence of good } \\
\text { substitute materials and services; V701-A5 = low switching costs for a firm; V702-A5 = } \\
\text { access to cheap material, energy and services; V701-A1 = large number of suppliers. }\end{array}$ \\
\hline & $\begin{array}{l}\text { V701-E2 = diverse competitors in the industry; V701-E3 = high exit barriers; V701-E5 = } \\
\text { heterogeneity of products/services in the industry; V701-D6 = government limitations as entry } \\
\text { barriers; V701-D2 = cost disadvantages (independent of scale) of new entrants as entry } \\
\text { barriers; V701-B7 = buyers' insufficient information on products/services; V701-B4 = } \\
\text { nonexistence of good substitute products/services in the industry; V701-D1 = economies of } \\
\text { scale as entry barriers; V701-E4 = rapid industry growth; V701-D4 = large capital } \\
\text { requirements as entry barriers; V701-D7 = psychological entry barriers; V701-D5 = limited } \\
\text { access to distribution channels as an entry barrier; V701-D3 = customer loyalty as an entry } \\
\text { barrier; V701-E1 = few competitors in the industry; V701-C = low threat of substitution; } \\
\text { V701-D = low threat of new entrants. }\end{array}$ \\
\hline 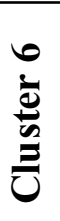 & $\begin{array}{l}\text { V301-B = quality of domestic demand; V301-C = size of domestic demand; V } 301-\mathrm{A}= \\
\text { quality of domestic factors of production; V301-D = positive influence of related and } \\
\text { supporting industries; V } 301-\mathrm{F}=\text { favourable influence of government policy; V301-G = } \\
\text { favourable influence of chance. }\end{array}$ \\
\hline
\end{tabular}


Fig. A2. Proposed classification of the forms of a firm's competitive advantage (dendrogram based on the 'Within-Groups Linkage' clustering method)

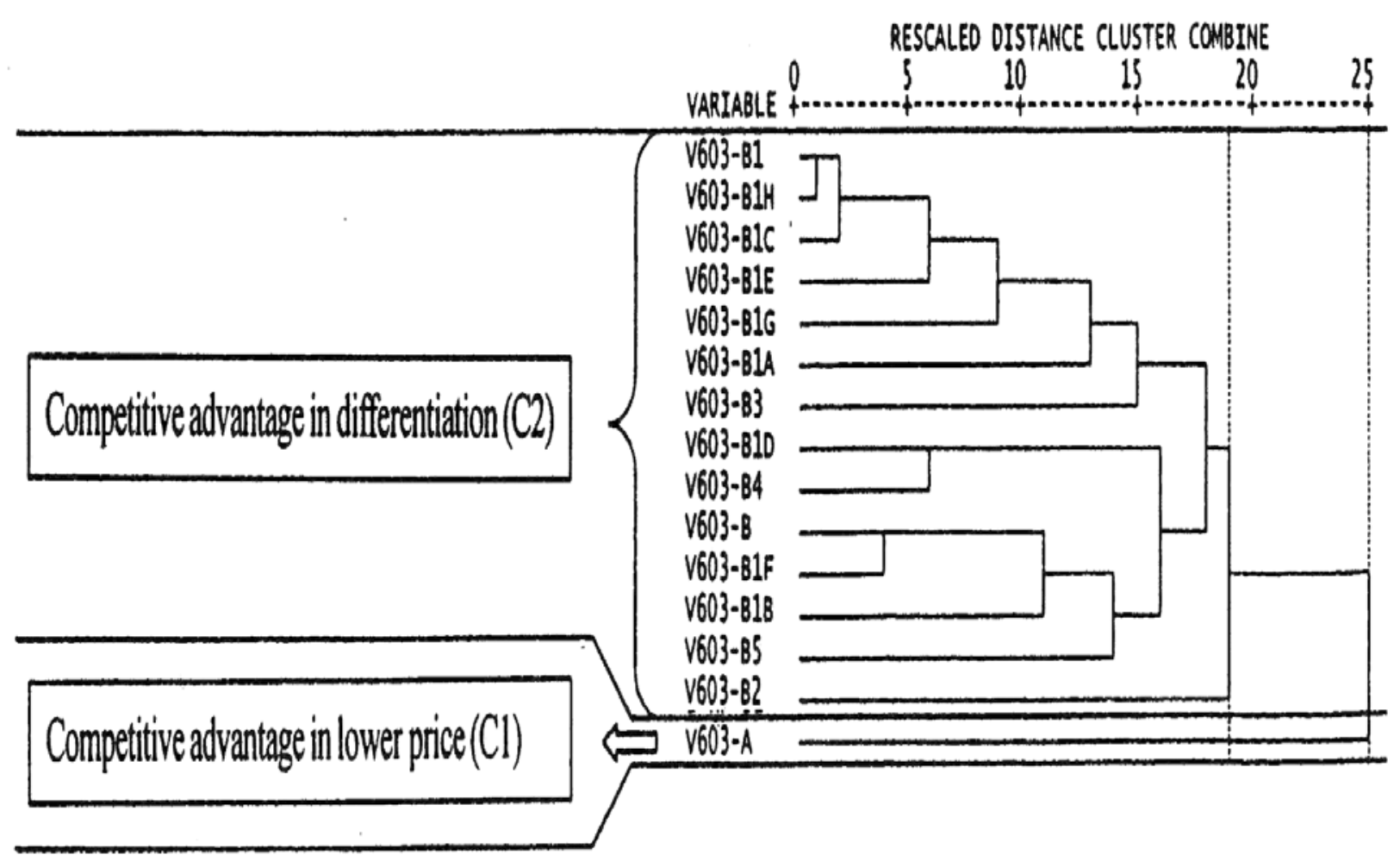

Table A2. Proposed classification of the forms of a firm's competitive advantage (description of the variables in Figure A2)

Cluster 1 $\mathrm{V} 603-\mathrm{A}=$ lower prices in comparison with competitors;

V603-B1 = superiority of a product/service; V603-B1H = customers' perception of a product/service; V603-B1C = reliability of a product/service; V603-B1E = durability of a product/service; V603-B1G = aesthetics of a product/service; V603-B1A = performance Cluster 2 of a product/service; V603-B3 = speed in satisfying customers' needs; V603-B1D = conformance of a product/service with different standards; V603-B4 = flexibility in satisfying customers' needs; V603-B = differentiation in comparison with competitors; $\mathrm{V} 603-\mathrm{B} 1 \mathrm{~F}=$ serviceability of $\mathrm{a}$ product; $\mathrm{V} 603-\mathrm{B} 1 \mathrm{~B}=$ special features of $\mathrm{a}$ product/service; V603-B5 = positive image of a firm; V603-B2 = totality of a firm's supply. 